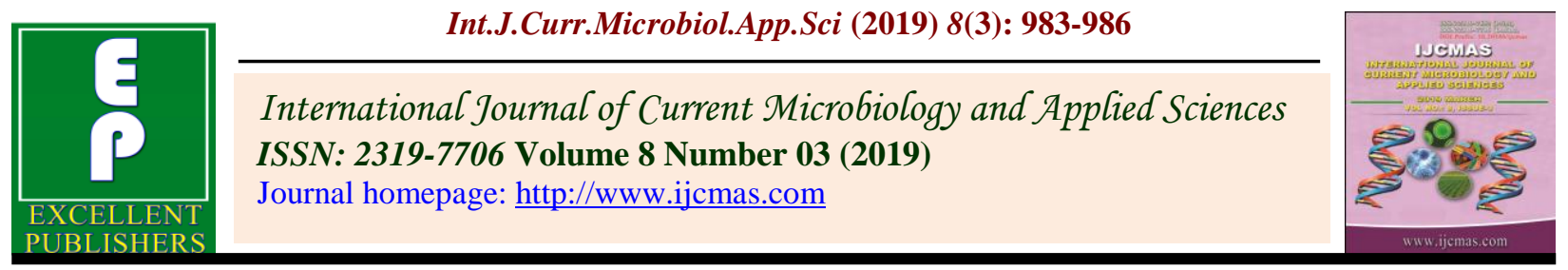

Case Study

https://doi.org/10.20546/ijcmas.2019.803.118

\title{
Bovine Tropical Theileriosis in Tharparkar Calves and its Therapeutic Management
}

\author{
N. Kumar, Monika* and K.P. Parmar
}

Department of Veterinary Parasitology, College of Veterinary and Animal Science, Bikaner, Rajasthan University of Veterinary and Animal Sciences, Bikaner-334001, India

*Corresponding author

\section{A B S T R A C T}

\begin{tabular}{|l|}
\hline Key w or d s \\
$\begin{array}{l}\text { Buparvaquone, } \\
\text { Calves, Tharparkar, } \\
\text { Theileria annulata }\end{array}$ \\
\hline Article Info \\
\hline $\begin{array}{l}\text { Accepted: } \\
\text { 10 February } 2019 \\
\text { Available Online: } \\
\text { 10 March } 2019\end{array}$ \\
\hline
\end{tabular}

\begin{abstract}
Bovine tropical theileriosis is a tick-borne haemoprotozoan disease of cattle caused by Theileria annulata. Theileria is one of the most important blood protozoan parasite and a major constraint to the dairy industry and causes devastating losses to the livestock worldwide. Theileria annulata have complex life cycle and is transmitted by Hyalomma anatolicum anatolicum transtidially. The present report demonstrates the successful therapeutic management of theileriosis in calves. Clinical examination of affected animals revealed high fever $\left(104{ }^{0} \mathrm{~F}\right)$, generalized enlargement of superficial lymph nodes, dullness, conjunctival petechia, anorexia and diarrhoea. The blood smears examination after staining revealed the presence of Theileria organisms. Buparvaquone was used as the drug of choice along with supportive therapy.
\end{abstract}

\section{Introduction}

Bovine tropical theileriosis, also known as Mediterranean coast fever, is an extremely fatal and debilitating tick-transmitted disease infecting various domesticated animals particularly cattle (Santos et al., 2013). Globally, the most common cause of bovine theileriosis is Theileria annulata and Theileria parva (Kohli et al., 2014; Gul et al., 2015). In the Indian subcontinent, bovine tropical theileriosis (BTT) caused by Theileria annulata has been persistently recognized as a major constraint to livestock improvement programmes. In enzootic areas, the disease accounts for high mortality up to
$70 \%$ in dairy cattle, especially calves and over 200 million animals are at risk (Radostits et al., 1994; Aiello and Mays, 1998). The BTT is a tick-borne, transtadially transmitted disease caused by Theileria annulata, involving Hyalomma anatolicum anatolicum as vector in the subcontinent. The host gets infected 2-4 days after next developmental instars of $H$. anatolicum anatolicum start feeding blood.

The total annual loss on Indian livestock sector due to BTT in India has been estimated to US\$ 384.3 million per annum (Minjauw and McLeod, 2003). Though all breeds of cattle are equally susceptible, but purebred, 
exotic, crossbreds as well as the young indigenous calves are comparatively at higher risk to theileriosis (Sharma and Gautam, 1977; Grewal, 1992). The present study documented bovine theileriosis in nine young Tharparkar calves aged between twenty days to three months and its effective management at livestock Research Station, Beechwal, Bikaner.

\section{Case history and observation}

Fifteen calves aged below three months were presented with a history of dullness, anorexia and high body temperature $\left(104{ }^{\circ} \mathrm{F}\right)$, pale mucous membrane, dyspnoea, posterior paresis, nasal discharge, anaemia, diarrhoea, bilateral pre scapular lymphadenitis and tick infestation. From each calf, peripheral blood (5 $\mathrm{ml}$ in EDTA) from jugular vein was aseptically collected and the ticks were also collected for identification. Rectal coprological samples were also collected.

The samples were brought to the Department of Veterinary Parasitology, College of Veterinary and Animal Science, Bikaner for identification of the pathogen(s) and its vectors using standard keys/techniques (Bowman, 2003; Taylor et al., 2007).

\section{Results and Discussion}

Clinical examination of the calves revealed lusterless dull hair coat infested with the developmental instars, including adult $H$. anatolicum anatolicum over dewlap, axilla, ventral abdomen, udder and around peri anal region.

The animal was weak and emaciated. The conjunctival mucous membrane was pale and icteric. The muzzle was dry with frothy nasal discharge from both the nostrils. There was excessive drooling salivation, besides, accelerated pulse and initially diarrhoic faces turn to almost dry and hard rectal faeces.

Out of fifteen animal blood smears examined nine calves harboured Theileria annulata organisms as the microscopic examination of Giemsa stained thin blood smear revealed characteristic intra erythrocytic piroplasms (Fig. 1a) and Koch's blue bodies (KBB) in the cytoplasm of the lymphocytes (Fig. 1b). Whereas, feacal samples could not demonstrate parasitic ova and cysts.

The characteristic clinical signs consistent with BTT coupled with demonstration of the pathogen in circulating erythrocytes collectively confirmed that the deceased calves suffered from $T$. annulata infection. Similarly Gupta et al., (2004) reported theileriosis in 7 day old bovine calf. According to Mudgal (1993) and Naik et al., (2010), the young calves of below one month of age are highly susceptible for theileriosis, hence proper immuno-prophylactic measures should be given to the calves immediately after birth under field conditions. Sharma and Nichani (1977) and Grewal (1992) opined that, the young calves are highly susceptible for theileriosis.

In the present study, the affected animals were treated with buparvaquone (Butalex at the dose rate of $2.5 \mathrm{mg} / \mathrm{kg}$ body weight) deep intramuscularly and advised to repeat after seven days. In addition, meloxicam (Melonex at the dose rate of $0.5 \mathrm{mg} / \mathrm{kg}$ body weight) intramuscularly for three days was also given. The calves were recovered and attains normalcy after one week of treatment. This is in accordance with Gupta et al., (2004) who used buparvoquone along with supportive therapy for the successful treatment. One blood smears did not revealed any haemoprotozoan parasites, but the animals were responded for the above said treatment. 
Fig.1 Giemsa stained thin blood smear showing intra erythrocytic piroplasms (a) and Koch blue bodies in the cytoplasm of the lymphocytes (b)

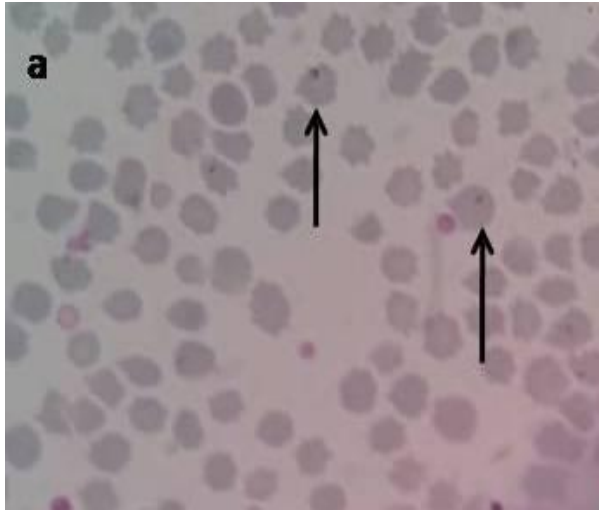

However, Buparvaquone is a promising compound for the therapy and prophylaxis of all forms of theileriosis; the adjunct of antioxidants to anti-theilerial agents can rescue the affected animals from fatal theileriosis. An in vitro attenuated schizontal cell culture vaccine is available with trade name of 'Rakshavac $T$ ' manufactured by Indian immunologicals limited, Hyderabad (Singh et al., 2014) to prevent BTT. So, it is further recommended that the high valued animals should be vaccinated with this vaccine to prevent them from bovine tropical theileriosis.

\section{References}

Aiello, S.E., and Mays, A. 1998. The Merck Veterinary Manual. $8^{\text {th }}$ ed., Merck \& Co. Inc. New Jersey, USA. pp 31-33.

Bowman, D.D. 2003. Georgi's Parasitology for Veterinarians. $8^{\text {th }}$ ed., SaundersAn imprint of Elsevier, St. Louis, pp $1-422$.

Grewal, A.S. 1992. Development of theilaria vaccine for control of bovine tropical theileriosis. In: Proceeding of Annual Scientist Meet of All India Coordinated Research Projects on "Intracellular blood protista with special reference to the immunoprophylaxis and control",

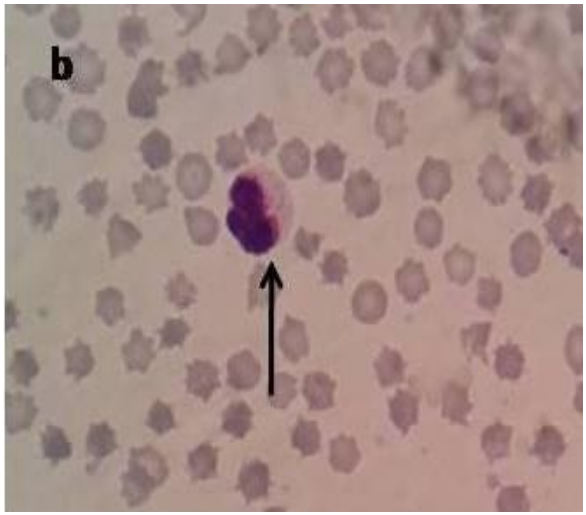

Haryana Agricultural University, Hisar, India. Feb 8, 1992.

Gul, N., Ayaz, S., Gul, I., Adnan, M., Shams, S., and ul Akbar, N. 2015. Tropical Theileriosis and East Coast Fever in Cattle: Present, Past and Future Perspective. International Journal of Current Microbiology and Applied Science. 4(8): 1000-1018

Gupta, S.K., Yadav, A., Raina, A.K., and Singh, R. 2004. Theileriosis in a seven-days old bovine calf- A case report. Indian Journal of Veterinary Medicine. 24(1): 55

Kohli, S., Atheya, U.K., and Thapliyal, A. 2014. Prevalence of theileriosis in cross- bred cattle: its detection through blood smear examination and polymerase chain reaction in Dehradun district, Uttarakhand, India. Veterinary World. 7(3): 168-171.

Minjauw, B. and McLeod, A. 2003. Tickborne diseases and poverty. The impact of ticks and tick-borne diseases on the livelihood and marginal livestock owners in India and Eastern and Southern Africa. Research report, DFID Animal Health Programme, Centre of Tropical Veterinary Medicine, University of Edinburgh.

Mudgal, V.K. 1993. Studies on crossimmunity and field trials with cell 
culture vaccine against bovine tropical theileriosis. M.V.Sc. Thesis, Haryana Agricultural University, Hisar, India.

Naik, G., Ananda, K.J., Rani, B.K. 2010. Theileriosis in calves and its successful treatment. Veterinary World. 3(4): 191.

Radostits, O., Gay, C., Hinchcliff, K., and Constable, P. 1994. Veterinary Medicine- A text book of the diseases of Cattle, Sheep, Pigs, Goats and Horses. $8^{\text {th }}$ ed., Bailliere Tindall, London, UK. pp 1210-1212.

Santos, M., Soares, R., Costa, P., Amaro, A., Inacio, J., and Gomes, J. 2013. Revisiting the Tams1-encoding gene as a species-specific target for the molecular detection of Theileria annulata in bovine blood samples. Ticks and Tick-borne Diseases. 4: 7277
Sharma, R.D. and Gautam, O.P. 1977. Theileriosis in cattle. Indian Journal of Parasitology. 1: 87-91

Sharma, R.D. and Nichani, A.K. 1990. A cell culture vaccine against bovine tropical theileriosis for young calves. In: Proceedings of first Asian Congress of Veterinary Parasitology, Bihar Veterinary College, Patna, India. Oct. 6-8, 1990.

Singh, A.K., Verma, A.K., Tiwari, R., Neha, Karthik, K., Dhama, K., and Singh, S.V. 2014. Trends and advances in vaccines against protozoan parasites of veterinary importance: a review. Journal of Biological Sciences. 14(2): 95-109.

Taylor, M.A., Coop, R.L., and Wall, R.L. 2007. Veterinary Parasitology. $3^{\text {rd }}$ ed., Oxford: Blackwell Publishing Ltd. pp. 109-113.

\section{How to cite this article:}

Kumar, Monika, N., and Parmar, K.P. 2019. Bovine Tropical Theileriosis in Tharparkar Calves and its Therapeutic Management. Int.J.Curr.Microbiol.App.Sci. 8(03): 983-986.

doi: https://doi.org/10.20546/ijcmas.2019.803.118 